\title{
Effects of Essential Fatty Acids Containing Natural and Commercial Diets on Larvae Rearing of the Green Mud Crab Scylla Paramamosain (Estampador 1949)
}

\author{
M. L. Islam ${ }^{1,2} *$, M. S. Islam ${ }^{3}$ K. Yahya ${ }^{4}$ and R. Hasim ${ }^{4}$ \\ ${ }^{1}$ Centre for Marine and Coastal Studies, University Sains Malaysia, Penang, Malaysia \\ ${ }^{2}$ Bangladesh Fisheries Research Institute; Brackishwater Station, Paikgacha, Khulna, Bangladesh \\ ${ }^{3}$ Universiti Malaysia Terengganu, Malaysia \\ ${ }^{4}$ School of Biological Sciences, University Sains Malaysia, Penang, Malaysia
}

Received 20 July 2016, accepted in final revised form 9 November 2016

\begin{abstract}
Effect of essential fatty acids (EFA) on growth and survival of the green mud crab (Scylla paramamosain) larvae was assessed by feeding with natural to commercial diets. The feeding schemes were: larvae reared with Artemia (T1); larvae initially fed with rotifers (up to Z2) and ended (Z3 to megalopa) with Artemia (T2); and larvae fed with rotifers up to Z2 and ended ( $\mathrm{Z} 3$ to megalopa) with commercial diet (T3). The commercial diet had significantly $(\mathrm{p}<0.05)$ higher levels of docosahexaenoic acid $(11.23 \%), \sum \mathrm{n}-3$ 's $(15.90 \%)$ and $\sum \mathrm{n}-6$ 's (4.21\%); and lacked in eicosapentaenoic acid (2.25\%) than rotifer and Artemia. The earliest commencement of megalopa stage within 15 days with significantly $(p<0.05)$ higher larval stage index (LSI) of 5.90 \pm 0.17 was achieved from the feeding scheme of T2 than other two feeding schemes. This feeding scheme deposited $17.32 \pm 0.19 \%$ eicosapentaenoic acid (EPA) and $3.82 \pm 0.11 \%$ docosahexaenoic acid (DHA); the $\sum \mathrm{n}-3$ to $\sum \mathrm{n}-6$ ratio of 0.20 and EPA to DHA ratio of 0.22 in megalopa, that stimulated significantly higher $(\mathrm{p}<0.05)$ megalopa survival $(20.00 \pm 6.96 \%)$ indicating the superiority over rest feeding schemes. Meanwhile, some deformities and mortalities in Z5 and megalopa stages suggested further studies for optimization of specific fatty acid requirements for late larval stages (Z5 and megalopa).
\end{abstract}

Keywords: Effects; Diets; EFA's; Larvae; Mud crab.

(C) 2017 JSR Publications. ISSN: 2070-0237 (Print); 2070-0245 (Online). All rights reserved. doi: http://dx.doi.org/10.3329/jsr.v9i1.28805 J. Sci. Res. 9 (1), 109-126 (2017)

\section{Introduction}

Mud crab aquaculture is an emergent sector in south-east Asian countries [1]. Since its starting to date, mud crab aquaculture is solely dependent on natural seeds [2,3]. Natural seeds are not sufficient enough to support the present status of the mud crab industry [4].

\footnotetext{
*Corresponding author: latiful.bfri@gmail.com
} 
Moreover, recent intervention of soft shell crab shedding has stimulated the scarcity of mud crab seeds [5]. In this circumstances, hatchery based seed production is the best alternate to support the present mud crab aquaculture and further expansion of this sector as well.

In the hatchery conditions, the survival rate of mud crab seeds from the zoea (Z1) to crablet stage is low and inconsistent [6] and ranging from $3.2 \%$ to $10 \%$ [7]. Mass mortality of larvae at the early zoeal stages (Z1 to Z2) is linked with improper nourishment from maternal source [6-8] and mud crab broodstock required high dietary requirement for lipids, fatty acids and protein for maturation and breeding [9]. The second mass mortality happened during metamorphosis in the late zoeal stages (Z5 to megalopa) is reportedly associated with nutritional inadequacy of the supplied diets [10-14]. Among the nutrients, long chained polyunsaturated omega-3 fatty acids (LC-PUFA) of eicosapentaenoic acid (EPA) and docosahexaenoic acid (DHA) are evidently responsible for proper functioning of cardiovascular, renal, nervous, immune and reproductive systems as well as the regulatory nutrient for the formation of brain and structure $[15,16]$. In crustaceans, EPA and DHA play vital role for the cytokine regulation [17] and outer shell formation [18], and the main component of the body shell is chitin. However, supply of improper nutritional diet is resulting in moulting failure of crustaceans, known as Moulting Death Syndrome (MDS). Moulting failure in mud crab larvae is associated with lack of essential fatty acids (EFAs), especially the eicosapentaenoic acid (EPA, 20:503) and docosahexaenoic acid (DHA, 22:6 13 ). Marine crustaceans including mud crab larvae are unable to synthesize these EFAs in situ or incapable of bio-converting from the parent omega-3 molecule of ALA linolenic acid ( $\alpha-18: 3 \omega 3)$. Therefore EFAs should be supplied through diet $[18,19]$. Boosting of EPA and DHA through enrichment of live prey provided better results in crab larvae rearing [20,21]. Some research on dietary EPA and DHA levels for mud crab larvae rearing has been done elsewhere [22]. Meanwhile, mud crab seed production in hatchery condition is a new attempt in Bangladesh and Malaysia. However, the aim of this experiment was to observe the implication of different natural and commercial diets containing various levels of essential fatty acids of EPA, DHA and their rations on growth, survival and metamorphosis of mud crab (Scylla paramamosain) larvae.

\section{Materials and Methods}

\subsection{Experimental design and protocol}

This experiment was conducted in three treatments based on three different diets (two species of live food and a commercial marine shrimp larval diet) used for different developmental stages of the crab larvae. In treatment-1 (T-1), larvae from Z1 to Z2 were fed with Artemia umbrella and from Z3 to megalopa with Artemia nauplii; in treatment-2 (T-2), larvae were reared on rotifers from $\mathrm{Z} 1$ to $\mathrm{Z} 2$ and Artemia nauplii from $\mathrm{Z} 3$ to megalopa; and in treatment-3 (T-3), larvae were fed rotifers from $\mathrm{Z} 1$ to $\mathrm{Z} 2$ and formulated 
shrimp larvae rearing microbound diet (Artemac, Bio-marine, Hawthorne, California, USA; grain size $20 \mu \mathrm{m}$ to $80 \mu \mathrm{m}$ and $60 \mu \mathrm{m}$ to $120 \mu \mathrm{m}$ ) from Z3 to megalopa. Each of the treatments was run in three replicates. The experiment was conducted in $1000 \mathrm{~L}$ round larvae rearing tanks with a water volume of $700 \mathrm{~L}$ of each. Larvae were stocked at a density of 80 larvae per liter of water.

The seawater (30 ppt) was pumped from the sea, passed through a gravel bed filter and stored in a fibre glass tank $\left(50 \mathrm{~m}^{3}\right.$ volume). Necessary water, hatchery utensils (glass wares, siphon pipe, bowls, buckets, filter bags, dip scoop net etc.) and hatching/incubation tanks were disinfected with 10-20 ppm of Clorox (5.25\% calcium hypochlorite) followed by dechlorination with sodium thiosulphate $[22,23]$.

Table 1. Detailed experimental design for mud crab larvae rearing.

\begin{tabular}{cccccc}
\hline \multirow{2}{*}{ Treatment } & Replication & \multicolumn{4}{c}{ Larval stages, feeding schemes and feed density } \\
\cline { 2 - 5 } T1 & 3 & $\begin{array}{c}\text { Artemia } \text { umbrella; } 0.5 \\
\text { to } 1.5 \text { ind./mL } \\
\text { Rotifer; } 40 \text { to } 60 \\
\text { ind./mL }\end{array}$ & Artemia nauplii; 1.5 to 10 ind./mL \\
T2 & 3 & $\begin{array}{c}\text { Rotifer; } 40 \text { to } 60 \\
\text { ind./mL }\end{array}$ & Artemia nauplii; 1.5 to 10 ind. $/ \mathrm{mL}$ \\
T3 & 3 & Commercial marine shrimp diet; 0.5 to 1.0 g/ton \\
\hline
\end{tabular}

\subsection{Live feed and commercial diet}

Commercial Artemia franciscana cysts (Premium Plus, Golden Dolphin, super Artemia, Sdn Bhd, Malaysia) were purchased from the supplier. Hydration, hatching and separation of umbrella type or nauplii of Artemia was performed [22,23]. Artemia cysts were hydrated and decapsulated in 20 ppt seawater with 10 ppm Clorox and vigorous aeration for $30 \mathrm{~min}$. Decapsulated cysts were rinsed repeatedly with filtered seawater (30 ppt salinity) to remove chlorine, and were then placed in the incubation bucket at the rate of $1.0 \mathrm{~g}$ cysts/L of sea water with vigorous aeration for $24 \mathrm{~h}$. After 18-24 h, the umbrella stage and nauplii were obtained, and were transferred into an inverted sharp edged conical jar covered with a plastic lid and left for $30 \mathrm{~min}$. for settling. They were then separated from the shell, and were repeatedly rinsed with clean seawater before feeding them to the mud crab larvae.

Marine phytoplankton (Nannochloropsis sp.) was cultured in cylindrical hanging plastic bags filled with disinfected filtered seawater, enriched with $1 \mathrm{~mL} / \mathrm{L}$ of Conway medium [24] and inoculating the stock solution at the rate of $0.1-0.5 \times 10^{7}$ cells $/ \mathrm{mL}$ of culture volume $[25,26]$. A secondary dose of medium $(0.5 \mathrm{~mL} / \mathrm{L})$ was added to the culture bags at 7 days of inoculation; the phytoplankton culture reached its peak $\left(9.4-10.5 \times 10^{7}\right.$ cells/mL) in $15-20$ days.

The rotifer (Brachionus plicatilis) culture was initiated in $300 \mathrm{~L}$ rectangular or 1000 $\mathrm{L}$ round tanks, filled with seawater (30 ppt salinity). A density of 20 rotifer/mL of culture volume was introduced and fed with baker's yeast at a rate of $0.25-0.50 \mathrm{~g}$ per million of 
rotifers twice a day [27]. The rotifers had grown to a density of $400 \pm 50$ individual $/ \mathrm{mL}$ in 5-7 days, and were harvested by siphoning and collected by passing through $50 \mu \mathrm{m}$ meshed dip nylon net. The harvested rotifers were repeatedly rinsed in filtered seawater and fed with the phytoplankton (Nannochloropsis sp.).

Rotifers grown in baker's yeast medium were harvested and enriched before 24-48 h. of feeding with phytoplankton (Nannochloropsis sp.) at the density of $\pm 1.5 \times 10^{6}$ cells $/ \mathrm{mL}$ per million of rotifer [28]. However, the umbrella type Artemia was not enriched, whereas, in the case of late stage feeding (Z3 to Z5) with Artemia, nauplii were enriched with commercial fish oil SELCO at the rate of $0.5 \mathrm{~g} / \mathrm{L}$ of sea water before 4 to $6 \mathrm{hr}$ of feeding time [28].

Commercial microbound diet formulated for rearing marine shrimp larvae (Artemac; Bio-marine, Inc.; Hawthorne, California, USA) was purchased from the supplier and kept in the refrigerator at $-20{ }^{\circ} \mathrm{C}$ for storage. The diet was labelled as follows: grain size 20 $120 \mu \mathrm{m}$, carbohydrate $12.0 \%$, protein $57.0 \%$, lipid $19.0 \%$, ash $5.0 \%$ and moisture 7.0 $\%$. The feed was also analysed for fatty acid profiles.

\subsection{Collection and management of crab broods (Base population, $P_{0}$ )}

Berried broods $\left(\mathrm{P}_{0}\right)$ collected from the wild and were purchased from traditional fishermen of Pulau Betong, Penang. The broods were brought to the CEMACS (Centre for Marine and Coastal Studies) hatchery by a covered plastic box filled with seawater (30 ppt salinity) and continuous aeration. Then morphological characteristics of the brood were examined to confirm the species [29]. They were acclimatized to the hatchery condition by placing in aerated seawater $\left(30 \mathrm{ppt}\right.$ and $\left.30^{\circ} \mathrm{C}\right)$ in plastic bucket for $1 \mathrm{hr}$. The broods were then disinfected in a plastic bucket containing $100 \mathrm{ppm}$ formalin (37\% formaldehyde) mixed seawater (30 ppt) for a period of $30 \mathrm{~min}$. with aeration followed by repeated washing with filtered seawater (30 ppt) to remove any residual formalin. They were then transferred into the hatching tank for housing/incubation until the larvae were hatched. During incubation time, feeding were ceased, aeration was kept at a moderate flow. The tank bottom was daily cleaned by siphoning and 50-70 \% of the water was exchanged everyday with treated seawater $(30 \mathrm{ppt})$. Water temperature, salinity, dissolved oxygen and $\mathrm{pH}$ were monitored in regular basis before the water exchange following standard methods [30].

\subsection{Preparation of larvae rearing tanks}

All the required tanks were prepared by setting up aeration and installing separate light (1,000 Lux; TYH ${ }^{\mathrm{TM}}, 100 \mathrm{~W}$, AC $\left.240 \mathrm{~V}, 50 / 60 \mathrm{HZ}\right)$ for each tank. Tanks were covered with canvas sheet to minimize temperature fluctuation and to prevent external contamination. Tanks were washed cleaned and dried. Before 1 week of initiating larvae culture, tanks were filled up (three fourth) with filtered seawater (30 ppt) and treated with 
$10 \mathrm{ppm}$ Clorox and left until stocking of larvae. Before stocking, residual chlorine was monitored and dechlorinated by treating with sodium thiosulphate.

\subsection{Collection, handling and stocking of larvae}

Immediately after full hatching of larvae from the egg mass, the phototaxis strong larvae were gently scooped up by a glass beaker and placed into an aerated plastic bucket filled with sea water $(30 \mathrm{ppt})$. Three sub-samples $(100 \mathrm{~mL}$ each) of larvae suspension were taken, counted separately and an average was made. Larvae were then stocked in the rearing tank according to the desired density (80 larvae per litre of culture water). Required larvae suspension for desired density was calculated according to the formula in below:

Volume of larvae suspension needed to stock (litre) $=\frac{D \times T}{z}$

Where, $\mathrm{D}=$ desired stocking density/L (80/L); $\mathrm{T}=$ volume of each culture tank in litre $(1000 \mathrm{~L}) ; \mathrm{Z}=$ density of larvae (larvae/L) in the stock bucket.

\subsection{Feeding, management and schedules}

For the $\mathrm{Z} 1$ to $\mathrm{Z} 2$ stages, the larvae were fed with rotifer (Brachionus plicatilis) at a density of $40-60$ individual $/ \mathrm{mL}$ in T2 and T3. The umbrella type Artemia was served as feed at a density of $0.5-1.5 \mathrm{ind} / \mathrm{mL}$ in $\mathrm{T} 1$ for the same larval stage. For the late zoeal stages (Z3 to Z5) feeding, Artemia nauplii were provided @ 1.5 to $10 \mathrm{ind} / \mathrm{mL}$ of culture water in T1 and T2. Commercial diet was supplied @ 0.5-1.0 g/ton of culture volume for the same stage feeding in T3. Microalgae (Nannochloropsis sp) was added in all the larvae culture tanks at the density of $0.5 \times 10^{6}$ cells $/ \mathrm{mL}$ for the first 3 days of culture. Feeding for each treatment was done thrice in a day at $8 \mathrm{hr}$ intervals (i.e. at $0800 \mathrm{hr}, 1600$ hr and $2400 \mathrm{hr})$.

\subsection{Water management and monitoring of water quality variables}

For the first 2 days, the water in the culture tanks was not changed except topping up (100 $\mathrm{L}$ and $150 \mathrm{~L}$ for $1^{\text {st }}$ and $2^{\text {nd }}$ day of culture, respectively) to the maximum mark of culture volume $(1000 \mathrm{~L})$. Later on, the water was changed from $30 \%$ to $50 \%$ daily with $30 \mathrm{ppt}$ saline water up to the Z5 stage. Water salinity was reduced to $27 \mathrm{ppt}$ from Z5 to megalopa stage by gradual decreasing of $0.5 \mathrm{ppt}$ in each water change. Water quality variables, like temperature $\left({ }^{\circ} \mathrm{C}\right)$, salinity $(\mathrm{ppt}), \mathrm{pH}$, dissolved oxygen $(\mathrm{mg} / \mathrm{L})$, ammonia $(\mathrm{mg} / \mathrm{L})$ and nitrate $(\mathrm{mg} / \mathrm{L})$ were monitored in each day before water change following standard methods [30]. 


\subsection{Determination of survival and growth}

Survival of larvae was monitored each day by counting larvae in triplicate sub-samples of $250 \mathrm{~mL}$ collected from different locations in each tank. The survival rate of larvae was calculated as in the following equation:

Survival rate $(\%)=\frac{\frac{N L O-N L n}{N L O}}{N L 100}$

Where, $\mathrm{NL}_{0}=$ Number of surviving larvae on day " 0 " and $\mathrm{NLn}=$ Number of surviving larvae on the day " $n$ ".

Growth of the larvae expressed as larval stage index (LSI) was estimated by picking 10 larvae from each tank and observing under a compound microscope to monitor the current stage of development [31]. A larva was considered for a specific stage (Z1 to Z5) depending upon morphological development (Z1 to Z5 or M). Discrete numbers of 1, 2, 3, 4, 5 and 6 were assigned for the developmental stages of zoea-1 (Z1), zoea-2 (Z2), zoea-3 (Z3), zoea-4 (Z4), zoea-5 (Z5) and megalopa (M), respectively. Larvae in a tank were considered as a specific larval stage when more than $80 \%$ of the larvae reached to that stage [32]. Finally, larval stage index (LSI) was calculated by using the formula in below:

Larval Stage Index $(\mathrm{LSI})=\frac{\left(\mathrm{L}_{1} \times \mathrm{N}_{1}\right)+\left(\mathrm{LL}_{2} \times \mathrm{N}_{2}\right)}{\mathrm{TN}}$

Where, $\mathrm{L} 1=$ counted number of zoea at late stage; $\mathrm{N} 1=$ assigned number for zoea at late stage; L2 = counted number of zoea at early stage; N2= Assigned number for zoea at early stage; and $\mathrm{TN}=$ total number of larvae observed in sample.

\subsection{Biochemical analysis}

For proximate and fatty acid analysis, each type of feed (rotifer, nauplii of Artemia and microbound diet) was collected immediately before feeding. The initial larvae sample was collected immediately after hatching and also those of produced megalopa for each feeding treatment were also collected. All types of the collected samples were packed separately in air tight zipped polythene bags, labeled accordingly and stored in the freezer $\left(-20^{\circ} \mathrm{C}\right)$. The collected samples were transferred into the low temperature freezer $\left(-180^{\circ} \mathrm{C}\right)$ and stored until proximate composition and fatty acid analysis were to be performed.

Moisture content was determined by drying the samples onto the infrared moisture determination scale (Precisa HA 60). Crude protein was analyzed according to Kjeldahl methods following digestion with concentrated sulphuric acid $\left(\mathrm{H}_{2} \mathrm{SO}_{4}\right)$, distillation with $40 \%$ sodium hydroxide $(\mathrm{NaOH})$ and titration with $0.1 \mathrm{~N}$ hydrochloric acid $(\mathrm{HCl})$ by using an automated protein quantification apparatus (VAPODEST 50S, Gerhardt, Wiesbaden, Germany). A constant factor of 6.25 was used to convert nitrogen into protein.

Crude lipid was analyzed through lipid extraction method using chloroform and methanol mixture 2:1 (v/v) [33]. Crude fibre was estimated on the residues left onto the filter paper by igniting and digestion with $5 \% \mathrm{H}_{2} \mathrm{So}_{4}$ and $40 \% \mathrm{NaOH}$. The ash content 
was estimated by burnt the samples in a muffle furnace at $550{ }^{\circ} \mathrm{C}$ for 5 to $6 \mathrm{hr}$. Quantitative analyses of fatty acids of the samples were performed as accordingly on collected fatty acid methyl esters (FAME) [34]. An internal standard, $1 \mu \mathrm{L}$ caproic acid methyl ester (6: 0 ) diluted in chloroform (1: 499, v/v) was added to $3 \mu \mathrm{L}$ dried FAME. The sample was vortexed and $1 \mu \mathrm{L}$ was injected to gas chromatography (GC) for analysis.

\subsection{Data analysis}

The collected data was computed in Microsoft Excel and was analyzed through SPSS version 20 and 22. ANOVA was done to observe the differences between treatments. A confidence level of $95 \%$ was considered and $\mathrm{p} \leq 0.05$ was regarded as a significant difference between the treatments.

\section{Results}

\subsection{Water quality variables}

Water temperature ranged from $29.2^{\circ} \mathrm{C}$ to $31.8^{\circ} \mathrm{C}$, salinity from $27.0 \mathrm{ppt}$ to $30.0 \mathrm{ppt}, \mathrm{pH}$ from 7.7 to 8.4 , Dissolved oxygen from $5.2 \mathrm{mg} / \mathrm{L}$ to $6.8 \mathrm{mg} / \mathrm{L}$ and $\mathrm{NO}_{2}$ between 0.00 $\mathrm{mg} / \mathrm{L}$ and $0.28 \mathrm{mg} / \mathrm{L}$, respectively in all the treatments of larvae rearing Table 2.

Table 2. Range of water quality variable during larvae rearing with different feeding schemes.

\begin{tabular}{llll}
\hline Variables & $\mathrm{T}-1$ & $\mathrm{~T}-2$ & $\mathrm{~T}-3$ \\
\hline Water Temperature $\left({ }^{\circ} \mathrm{C}\right)$ & $29.4-30.0$ & $29.3-29.8$ & $29.2-29.8$ \\
Salinity $(\mathrm{ppt})$ & $27.0-30.0$ & $27.0-30.0$ & $27.0-30.0$ \\
$\mathrm{pH}$ & $7.7-8.2$ & $7.7-8.4$ & $7.8-8.4$ \\
$\mathrm{Dissolved} \mathrm{Oxygen}(\mathrm{mg} / \mathrm{L})$ & $5.3-6.4$ & $5.3-6.8$ & $5.2-6.5$ \\
$\mathrm{NO}_{2}(\mathrm{mg} / \mathrm{L})$ & $0.00-0.25$ & $0.00-0.25$ & $0.00-0.28$ \\
\hline
\end{tabular}

Concentration in $\mathrm{NH}_{4}$ gradually increased up to $1.50 \mathrm{mg} / \mathrm{L}$ in $\mathrm{T} 3$ with increasing the larvae rearing duration and a slimy layer on the bottom and tank wall was noticed. The levels of $\mathrm{NH}_{4}$ in $\mathrm{T} 3$ showed a significant difference $(\mathrm{p}<0.05)$ from day 6 of culture onward than $\mathrm{T} 1$ and $\mathrm{T} 2$ (Fig. 1).

\subsection{Proximate and fatty acid composition of larvae feeds}

Among the tested feeds, commercial diet contained significantly higher $(\mathrm{p}<0.05)$ levels of protein $(56.43 \%)$ followed by Artemia $(54.51 \%)$ and rotifer $(47.81 \%)$. As to the lipid level, Artemia ranked at the top with $14.41 \%$ lipid and had no significant difference $(p>0.05)$ to the lipid level of commercial diet (13.49\%). However, rotifer contained a significantly lower $(\mathrm{p}<0.05)$ lipid level $(12.18 \%)$ among all the diets (Table 3$)$. 


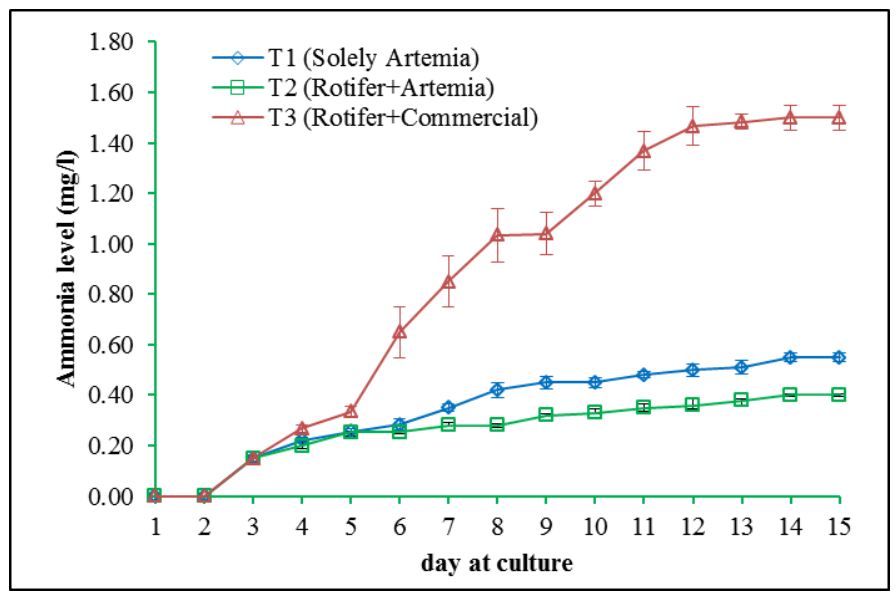

Fig. 1. Trend of ammonia $\left(\mathrm{NH}_{4}\right)$ under different feeding regimens of the green mud crab larvae rearing.

Table 3. Proximate composition of feeds (mean \pm SD) fed to the mud crab larvae under different feeding treatments.

\begin{tabular}{llll}
\hline Proximate $(\mathrm{g} / 100 \mathrm{~g})$ & Artemia & Rotifers & Commercial diet \\
\hline Moisture & $13.39 \pm 1.02^{\mathrm{a}}$ & $11.12 \pm 0.59^{\mathrm{b}}$ & $8.40 \pm 0.18^{\mathrm{c}}$ \\
Protein & $54.51 \pm 0.40^{\mathrm{b}}$ & $47.81 \pm 0.48^{\mathrm{c}}$ & $56.43 \pm 0.06^{\mathrm{a}}$ \\
Lipid & $14.41 \pm 0.54^{\mathrm{a}}$ & $12.18 \pm 0.51^{\mathrm{c}}$ & $13.49 \pm 0.32 \mathrm{~b}^{\mathrm{a}}$ \\
Ash & $7.66 \pm 0.81^{\mathrm{c}}$ & $11.26 \pm 0.26^{\mathrm{b}}$ & $12.52 \pm 0.28^{\mathrm{a}}$ \\
\hline
\end{tabular}

Note: different superscripts in same row indicates significant differences $(p<0.05)$, shared superscripts in the same row indicate an insignificant difference $(\mathrm{p}>0.05)$, and $\mathrm{a}>\mathrm{b}>\mathrm{c}$.

In case of fatty acid composition of the diets (Table 4), SFA (Saturated fatty acid) was dominated $(36.76 \%)$ in rotifers followed by commercial diet $(29.82 \%)$ and Artemia $(23.03 \%)$. The SFA level in rotifers was very close to that of the initial larvae sample (39.87\%). The MUFA (Monounsaturated fatty acid) level was dominated in Artemia $(35.62 \%)$ followed by rotifers $(33.65 \%)$ and commercial diet $(30.26 \%)$. The level of PUFA (Polyunsaturated fatty acid) was significantly higher $(\mathrm{p}<0.05)$ in Artemia $(41.35 \%)$ than in commercial diet (39.92\%) and rotifers (29.59\%).

In the commercial diet, ARA (Arachidonic acid) and DHA (Docosahexaenoic acid) levels were higher than in other feeds. On the other hand, EPA (eicosapentaenoic acid) was higher in the rotifer, followed by Artemia and commercial diet. The commercial diet contained significantly higher $(\mathrm{p}<0.05)$ levels of $n-3$ and $n-6$ fatty acids than the other two types of tested feeds. The ratio of DHA: EPA was significantly higher $(\mathrm{p}<0.05)$ in commercial diet $(5.03 \pm 0.48: 1)$, followed by rotifer $(0.29 \pm 0.05: 1)$ and Artemia $(0.16 \pm 0.02: 1)$ (Table 4). 
Table 4. Fatty acid composition (\% of total fatty acid detected) of initial larvae sample and tested feeds (mean $\pm \mathrm{SD}$ ) fed to the mud crab larvae.

\begin{tabular}{|c|c|c|c|c|}
\hline Fatty acids & Initial larvae (Z1) & Artemia & Rotifers & Commercial diet \\
\hline C14:0 & $0.74 \pm 0.07^{\mathrm{d}}$ & $1.89 \pm 0.02^{\mathrm{c}}$ & $3.40 \pm 0.01^{\mathrm{b}}$ & $3.86 \pm 0.14^{\mathrm{a}}$ \\
\hline $\mathrm{C} 16: 0$ & $20.64 \pm 0.41^{\mathrm{c}}$ & $15.22 \pm 0.13^{\mathrm{d}}$ & $23.45 \pm 0.13^{\mathrm{a}}$ & $21.61 \pm 0.50^{\mathrm{b}}$ \\
\hline C18:0 & $15.29 \pm 0.25^{\mathrm{a}}$ & $5.06 \pm 0.04^{\mathrm{c}}$ & $8.24 \pm 0.02^{\mathrm{b}}$ & $4.08 \pm 0.02^{\mathrm{d}}$ \\
\hline C20:0 & $1.11 \pm 0.10^{\mathrm{a}}$ & $0.43 \pm 0.08^{\mathrm{c}}$ & $0.73 \pm 0.02^{\mathrm{b}}$ & $0.13 \pm 0.02^{\mathrm{d}}$ \\
\hline $\mathrm{C} 22: 0$ & $0.97 \pm 0.08^{\mathrm{a}}$ & $0.21 \pm 0.00^{c}$ & $0.60 \pm 0.01^{\mathrm{b}}$ & ND \\
\hline $\mathrm{C} 24: 0$ & $1.11 \pm 0.08^{\mathrm{a}}$ & $0.22 \pm 0.03^{c}$ & $0.35 \pm 0.06^{\mathrm{b}}$ & $0.15 \pm 0.01^{\mathrm{dc}}$ \\
\hline$\sum$ SFA & $39.87 \pm 0.41^{\mathrm{a}}$ & $23.03 \pm 0.11^{d}$ & $36.76 \pm 0.11^{b}$ & $29.82 \pm 0.62^{c}$ \\
\hline$\overline{\mathrm{C}} 14: 1$ & ND & $0.24 \pm 0.00^{\mathrm{b}}$ & $1.94 \pm 0.00^{\mathrm{a}}$ & $0.14 \pm 0.00^{c}$ \\
\hline C16:1 & $4.02 \pm 0.07^{\mathrm{d}}$ & $11.58 \pm 0.03^{\mathrm{a}}$ & $9.01 \pm 0.06^{\mathrm{b}}$ & $6.60 \pm 0.10^{c}$ \\
\hline $\mathrm{C} 18: \ln 9 \mathrm{t}$ & ND & $0.19 \pm 0.03^{\mathrm{c}}$ & $2.09 \pm 0.00^{\mathrm{a}}$ & $0.34 \pm 0.03^{\mathrm{b}}$ \\
\hline $\mathrm{C} 18: 1 \mathrm{n} 9 \mathrm{c}$ & $11.52 \pm 0.76^{\mathrm{d}}$ & $23.10 \pm 0.14^{\mathrm{a}}$ & $16.49 \pm 0.20^{\mathrm{cb}}$ & $17.00 \pm 0.17^{\mathrm{b}}$ \\
\hline C20:1n9 & $1.06 \pm 0.13^{\mathrm{c}}$ & $0.29 \pm 0.07^{\mathrm{d}}$ & $2.40 \pm 0.04^{\mathrm{b}}$ & $4.72 \pm 0.30^{\mathrm{a}}$ \\
\hline C22:1n9 & ND & ND & $0.77 \pm 0.10^{\mathrm{a}}$ & $0.61 \pm 0.07^{\mathrm{b}}$ \\
\hline $\mathrm{C} 24: 1 \mathrm{n} 9$ & $0.27 \pm 0.06^{c}$ & $0.22 \pm 0.01^{\mathrm{dc}}$ & $0.95 \pm 0.07^{\mathrm{a}}$ & $0.85 \pm 0.02^{\mathrm{b}}$ \\
\hline$\sum$ MUFA & $16.86 \pm 0.69^{d}$ & $35.62 \pm 0.10^{\mathrm{a}}$ & $33.65 \pm 0.09^{b}$ & $30.26 \pm 0.45^{\mathrm{c}}$ \\
\hline $\mathrm{C} 18: 2 \mathrm{n} 6 \mathrm{t}$ & $0.32 \pm 0.04^{\mathrm{b}}$ & ND & $0.40 \pm 0.02^{\mathrm{a}}$ & $0.31 \pm 0.02^{\mathrm{cb}}$ \\
\hline $\mathrm{C} 18: 2 \mathrm{n} 6 \mathrm{c}$ & $1.00 \pm 0.09^{\mathrm{d}}$ & $11.45 \pm 0.06^{\mathrm{c}}$ & $12.65 \pm 0.05^{\mathrm{a}}$ & $11.77 \pm 0.09^{\mathrm{b}}$ \\
\hline C20:2 & $0.99 \pm 0.08^{\mathrm{a}}$ & $0.22 \pm 0.01^{\mathrm{dc}}$ & $0.58 \pm 0.02^{\mathrm{b}}$ & $0.22 \pm 0.01^{\mathrm{c}}$ \\
\hline $\mathrm{C} 22: 2$ & ND & $11.69 \pm 0.12^{\mathrm{a}}$ & ND & $7.51 \pm 0.39^{\mathrm{b}}$ \\
\hline C18:3n3 (ALA) & $0.22 \pm 0.02^{\mathrm{d}}$ & $8.43 \pm 0.09^{\mathrm{a}}$ & $3.01 \pm 0.04^{\mathrm{b}}$ & $2.30 \pm 0.08^{c}$ \\
\hline $\mathrm{C} 20: 3 \mathrm{n} 3$ & $0.22 \pm 0.02^{\mathrm{cb}}$ & $0.24 \pm 0.01^{\mathrm{b}}$ & $0.59 \pm 0.01^{\mathrm{a}}$ & $0.13 \pm 0.01^{\mathrm{d}}$ \\
\hline $\mathrm{C} 20: 5 \mathrm{n} 3$ (EPA) & $15.70 \pm 0.92^{\mathrm{a}}$ & $5.12 \pm 0.03^{\mathrm{c}}$ & $7.70 \pm 0.04^{b}$ & $2.25 \pm 0.21^{\mathrm{d}}$ \\
\hline C22:6n3 (DHA) & $13.39 \pm 0.35^{\mathrm{a}}$ & $0.84 \pm 0.10^{\mathrm{d}}$ & $2.22 \pm 0.06^{\mathrm{c}}$ & $11.23 \pm 0.07^{\mathrm{b}}$ \\
\hline $\mathrm{C} 18: 3 \mathrm{n} 6$ & ND & $0.50 \pm 0.00^{\mathrm{a}}$ & $0.29 \pm 0.01^{\mathrm{b}}$ & ND \\
\hline C20:3n6 & ND & $2.63 \pm 0.18^{\mathrm{a}}$ & $1.26 \pm 0.02^{\mathrm{b}}$ & $0.64 \pm 0.02^{\mathrm{c}}$ \\
\hline C20:4n6 (ARA) & $11.43 \pm 0.81^{\mathrm{a}}$ & $0.24 \pm 0.02^{\mathrm{dc}}$ & $0.89 \pm 0.00^{\mathrm{c}}$ & $3.56 \pm 0.13^{\mathrm{b}}$ \\
\hline$\sum$ PUFA & $43.27 \pm 0.62^{\mathrm{a}}$ & $41.35 \pm 0.21^{b}$ & $29.59 \pm 0.15^{\mathrm{d}}$ & $39.92 \pm 0.17^{\mathrm{c}}$ \\
\hline$\sum$ UFA & $60.13 \pm 0.41^{\mathrm{d}}$ & $76.97 \pm 0.11^{\mathrm{a}}$ & $63.24 \pm 0.11^{\mathrm{c}}$ & $70.18 \pm 0.62^{\mathrm{b}}$ \\
\hline$\sum(n-3)$ & $29.53 \pm 0.61^{\mathrm{a}}$ & $14.63 \pm 0.19^{c}$ & $13.52 \pm 0.14^{\mathrm{d}}$ & $15.90 \pm 0.24^{\mathrm{b}}$ \\
\hline$\sum(n-6)$ & $11.43 \pm 0.81^{\mathrm{a}}$ & $3.37 \pm 0.16^{c}$ & $2.44 \pm 0.02^{\mathrm{d}}$ & $4.21 \pm 0.12^{\mathrm{b}}$ \\
\hline UFA: SFA & $1.51 \pm 0.03: 1^{\mathrm{d}}$ & $3.34 \pm 0.02: 1^{\mathrm{a}}$ & $1.72 \pm 0.01: 1^{\mathrm{c}}$ & $2.35 \pm 0.07: 1^{\mathrm{b}}$ \\
\hline$(n-6):(n-3)$ & $0.39 \pm 0.03: 1^{\mathrm{a}}$ & $0.23 \pm 0.01: 1^{\mathrm{cb}}$ & $0.18 \pm 0.00: 1^{\mathrm{d}}$ & $0.26 \pm 0.01: 1^{\mathrm{b}}$ \\
\hline DHA: EPA & $0.86 \pm 0.07: 1^{\mathrm{b}}$ & $0.16 \pm 0.02: 1^{\mathrm{d}}$ & $0.29 \pm 0.05: 1^{\mathrm{c}}$ & $5.03 \pm 0.48: 1^{\mathrm{a}}$ \\
\hline
\end{tabular}

Notes: $\mathrm{ND}=$ not detected; different superscripts in same row indicate significant differences $(p<0.05)$, shared superscripts in the same row indicate an insignificant difference $(p>0.05)$, and $\mathrm{a}>\mathrm{b}>\mathrm{c}>\mathrm{d}$

\subsection{Survival rate of larvae}

The survival was higher in T2 and T3 for the initial three days (Fig. 2) when larvae were fed with rotifers. On the other hand, an initial mortality was noticed in T1 within $72 \mathrm{~h}$, when the larvae were fed with Artemia umbrella.

On the fifth day of rearing, a sudden fall in survival was marked in all the treatments, while it was drastically so in $\mathrm{T} 1$ and $\mathrm{T} 3$, when the feeding was changed from Artemia umbrella to nauplii and rotifer to commercial diet, respectively. In T2, the mortality was 
steady and the survival rate was found to be significantly higher $(\mathrm{p}<0.05)$ from the fourth to the fifteenth day of rearing (Fig. 2).

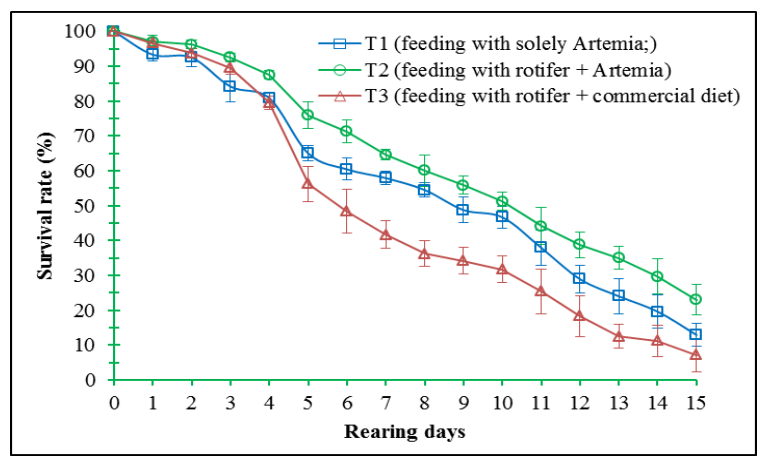

Fig. 2. Trends in daily survival (\%) of the green mud crab larvae fed with different feeding schemes.

Table 5. Survival rate $(\%)$ of the green mud crab larvae (Mean \pm SD) at different larval stages reared with different feeds.

\begin{tabular}{cccc}
\hline Larvae stages & $\begin{array}{c}\text { T1 } \\
(\text { Artemia })\end{array}$ & $\begin{array}{c}\text { T2 } \\
(\text { Rotifer }+ \text { Artemia })\end{array}$ & $\begin{array}{c}\text { T3 } \\
\text { (Rotifer + Commercial diet) }\end{array}$ \\
\hline Z2 & $84.17 \pm 4.39^{\mathrm{cb}}$ & $92.50 \pm 1.25^{\mathrm{a}}$ & $89.58 \pm 1.91^{\mathrm{ba}}$ \\
Z3 & $60.00 \pm 3.75^{\mathrm{b}}$ & $72.50 \pm 2.50^{\mathrm{a}}$ & $41.67 \pm 4.02^{\mathrm{c}}$ \\
Z4 & $48.75 \pm 3.75^{\mathrm{b}}$ & $56.67 \pm 1.91^{\mathrm{a}}$ & $32.50 \pm 4.33^{\mathrm{c}}$ \\
Z5 & $25.67 \pm 6.00^{\mathrm{b}}$ & $40.42 \pm 1.91^{\mathrm{a}}$ & $11.25 \pm 4.51^{\mathrm{c}}$ \\
M & $10.67 \pm 3.41^{\mathrm{b}}$ & $20.00 \pm 6.96^{\mathrm{a}}$ & $3.00 \pm 2.65^{\mathrm{c}}$ \\
\hline
\end{tabular}

Notes: $\mathrm{Z} 2 \ldots \ldots . \mathrm{Z} 5=$ zoea stage 2 to 5 and $\mathrm{M}=$ megalopa; different superscripts in same row indicate significant differences $(p<0.05)$, shared superscripts in the same row indicate an similarity $(p>0.05)$, and $a>b>c$.

The survival rate of larvae according to the different developmental stages of all feeding treatments is shown in Table 5. The survival rate for the Z2 stage was similar between T2 $(92.90 \%)$ and T3 $(89.58 \%)$ also between T3 and T1 $(84.17 \%)$, but it was significantly different $(\mathrm{p}<0.05)$ between $\mathrm{T} 2$ and $\mathrm{T} 1$. From the $\mathrm{Z} 3$ to $\mathrm{Z} 5$ stages, the survival rates were significantly $(\mathrm{p}<0.05)$ different among the treatments with highest values in $\mathrm{T} 2$ followed by T1 and T3. At the megalopa stage, survival rate was $10.67 \%, 20.00 \%$ and $3.00 \%$ in $\mathrm{T} 1, \mathrm{~T} 2$ and $\mathrm{T} 3$, respectively and differed statistically $(\mathrm{p}<0.05)$. Megalopa produced in $\mathrm{T} 3$ seemed very weak and were smaller in size (Table 7) thus unable to reach to the crablet stage (crab instars). Feeding treatments with enriched rotifers as a first feeding ( $\mathrm{Z} 1$ to $\mathrm{Z} 2$ ) followed by enriched Artemia nauplii as later stages (Z3 to megalopa) augmented higher survival rates in $\mathrm{Z} 5$ and megalopa stages.

\subsection{Larval stage index (LSI)}

Trends in the larval stage index (LSI) under different feeding treatments are presented in Fig. 3. It could be seen that, the LSI of larvae was similar up to day four. Later on the LSI 
began to vary between different feeding treatments and continued up to the fifteenth day. From day four onwards, T2 showed the highest LSI values followed by T1 and T3 (Fig. 3).

Larval stage index (LSI) at every three days is presented in Table 6. On day three, the LSI values were insignificant $(\mathrm{p}>0.05)$ among the treatments, indicating synchronized growth in all treatments. On the sixth day of rearing, the highest LSI value (3.00) was achieved in T2 with SD value of 0.00 , which indicated synchronized growth in all the replicates and it was significantly $(\mathrm{p}<0.05)$ higher than T3. However, it was statistically insignificant ( $>>0.05)$ between $\mathrm{T} 1$ and T2. The earliest commencement of highest LSI value of 5.0 (Z5 stage) was obtained in T2 on the twelfth day of culture and it was significantly higher $(\mathrm{p}<0.05)$ than $\mathrm{T} 1$ (4.67) followed by T3 (4.37). On the fifteenth day of culture, the LSI values were 5.51, 5.90 and 5.33 in T1, T2 and T3, respectively. The LSI value on the fifteenth day was statistically significant $(\mathrm{p}<0.05)$ between $\mathrm{T} 2$ and $\mathrm{T} 1$ followed by $\mathrm{T} 3$, but it was insignificant $(\mathrm{p}>0.05)$ between $\mathrm{T} 1$ and $\mathrm{T} 3$. The level of LSI value on the fifteenth day of culture indicated that more than $80 \%$ of larvae in T2 metamorphosed to the megalopa stage, whilst in T1 and T3 achieved $\leq 50 \%$ of megalopa on the fifteenth day of rearing (Table 6).

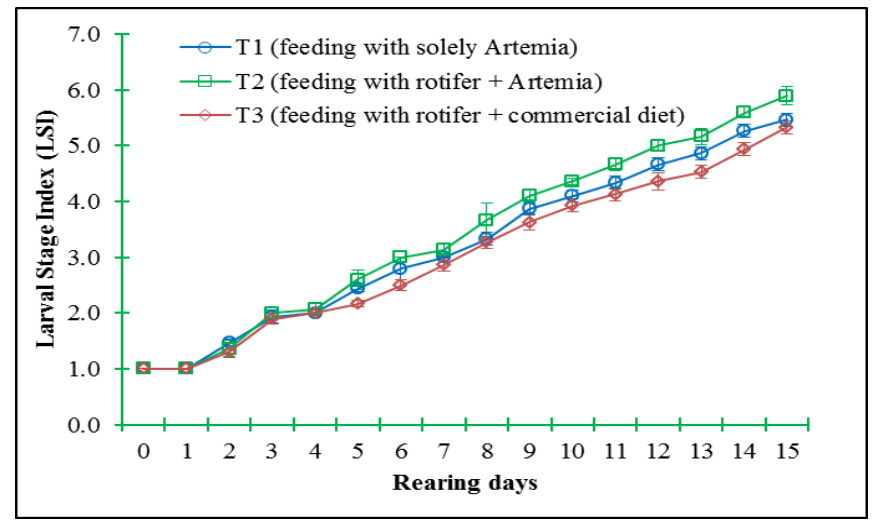

Fig. 3. Daily pattern of larval stage index (LSI) under different feeding schemes during larvae rearing period of the green mud crab.

Table 6. Larval stage index (LSI) (mean \pm SD) on each 3 day interval of the green mud crab larvae reared with different feeding schemes.

\begin{tabular}{llll}
\hline Rearing days & $\begin{array}{l}\text { T1 } \\
(\text { Artemia })\end{array}$ & $\begin{array}{l}\text { T2 } \\
\text { (Rotifer + Artemia })\end{array}$ & $\begin{array}{l}\text { T3 } \\
\text { (Rotifer + Inert) }\end{array}$ \\
\hline Day 3 & $1.93 \pm 0.12^{\mathrm{ba}}$ & $2.00 \pm 0.00^{\mathrm{a}}$ & $1.90 \pm 0.10^{\mathrm{cba}}$ \\
Day 6 & $2.80 \pm 0.20^{\mathrm{ba}}$ & $3.00 \pm 0.00^{\mathrm{a}}$ & $2.50 \pm 0.10^{\mathrm{c}}$ \\
Day 9 & $3.87 \pm 0.12^{\mathrm{ba}}$ & $4.10 \pm .10^{\mathrm{a}}$ & $3.63 \pm 0.15^{\mathrm{cb}}$ \\
Day 12 & $4.67 \pm 0.12^{\mathrm{b}}$ & $5.0 \pm 0.10^{\mathrm{a}}$ & $4.37 \pm 0.15^{\mathrm{c}}$ \\
Day 15 & $5.47 \pm 0.12^{\mathrm{b}}$ & $5.9 \pm 0.17^{\mathrm{a}}$ & $5.33 \pm 0.12^{\mathrm{cb}}$ \\
\hline
\end{tabular}

Notes: $\mathrm{ND}=$ not determined, different superscripts in the same row indicate significant differences $(\mathrm{p}<0.05)$, shared superscripts in the same row indicate an insignificant difference $(p>0.05)$, and $a>b>c$. 


\subsection{Larvae sizes at different stages}

Size of larvae at different stages under different feeding treatments is as shown in Table 7. Up to the Z2 stage, larvae size was similar in all treatments. From Z3 to the megalopa stages, larvae size was significantly smaller $(\mathrm{p}<0.05)$ in $\mathrm{T} 3$, but it was similar in $\mathrm{T} 1$ and T2 (Table 7).

Table 7. Size $(\mathrm{mm})$ of the mud crab larvae (mean $\pm \mathrm{SD}$ ) at various larval stages under different feeding schemes.

\begin{tabular}{|c|c|c|c|}
\hline Larvae stages & $\begin{array}{l}\text { T1 } \\
(\text { Artemia })\end{array}$ & $\begin{array}{l}\mathrm{T} 2 \\
(\text { Rotifer }+ \text { Artemia })\end{array}$ & $\begin{array}{l}\text { T3 } \\
\text { (Rotifer + Inert) }\end{array}$ \\
\hline Z1 (initial) & $2.17 \pm 0.01^{\mathrm{a}}$ & $2.17 \pm 0.01^{\mathrm{a}}$ & $2.17 \pm 0.01^{\mathrm{a}}$ \\
\hline $\mathrm{Z2}$ & $2.20 \pm 0.01^{\mathrm{a}}$ & $2.20 \pm 0.01^{\mathrm{a}}$ & $2.20 \pm 0.01^{\mathrm{a}}$ \\
\hline $\mathrm{Z3}$ & $2.88 \pm 0.01^{\mathrm{a}}$ & $2.88 \pm 0.01^{\mathrm{a}}$ & $2.82 \pm 0.01^{\mathrm{b}}$ \\
\hline $\mathrm{Z} 4$ & $2.92 \pm 0.02^{\mathrm{ba}}$ & $2.93 \pm 0.02^{\mathrm{a}}$ & $2.87 \pm 0.03^{c}$ \\
\hline $\mathrm{Z5}$ & $3.69 \pm 0.02^{\mathrm{ba}}$ & $3.71 \pm 0.01^{\mathrm{a}}$ & $3.64 \pm 0.04^{\mathrm{c}}$ \\
\hline M & $3.31 \pm 0.02^{\mathrm{ba}}$ & $3.32 \pm 0.01^{\mathrm{a}}$ & $3.20 \pm 0.02^{\mathrm{c}}$ \\
\hline
\end{tabular}

Notes: $\mathrm{ND}=$ not determined, Z1: zoea-1...... Z5: Zoea-5 and M: megalopa; different superscripts in same row indicate significant differences $(\mathrm{p}<0.05)$, shared superscripts in the same row indicate an insignificant difference $(\mathrm{p}>0.05)$, and $\mathrm{a}>\mathrm{b}>\mathrm{c}$

\subsection{Fatty acid composition of megalopa under different feeding treatments}

As shown in Table 8, the saturated fatty acid (SFA) content was significantly different $(\mathrm{p}<0.05)$ in megalopa between all feeding treatments with the highest level of $46.60 \%$ in T3 where larvae were fed with rotifer and commercial diet. Monounsaturated fatty acid (MUFA) was similar to the megalopa sample produced from all treatments. Polyunsaturated fatty acid (PUFA) seemed statistically different $(\mathrm{p}<0.05)$ among all treatments with the highest level $(42.68 \%)$ in megalopa derived from T1 where larvae were reared with Artemia umbrella followed by Artemia nauplii enriched with SELCO (commercial marine fish oil).

Table 8 . Fatty acid composition of megalopa (mean \pm SD) fed with different feeds at larvae rearing.

\begin{tabular}{|c|c|c|c|}
\hline Fatty acids & $\begin{array}{l}\text { Artemia } \\
\text { (T-1) }\end{array}$ & $\begin{array}{l}\text { Rotifer + Artemia } \\
\text { (T-2) }\end{array}$ & $\begin{array}{l}\text { Rotifer + Inert } \\
\text { (T-3) }\end{array}$ \\
\hline C14:0 & $0.55 \pm 0.01^{\mathrm{c}}$ & $0.66 \pm 0.01^{b}$ & $1.64 \pm 0.02^{\mathrm{a}}$ \\
\hline C16:0 & $17.26 \pm 0.04^{\mathrm{b}}$ & $16.92 \pm 0.11^{\mathrm{c}}$ & $21.44 \pm 0.12^{\mathrm{a}}$ \\
\hline C18:0 & $14.82 \pm 0.02^{b}$ & $13.08 \pm 0.08^{\mathrm{c}}$ & $15.87 \pm 0.20^{\mathrm{a}}$ \\
\hline C20:0 & $0.45 \pm 0.02^{\mathrm{b}}$ & $0.18 \pm 0.00^{c}$ & $6.55 \pm 0.17^{\mathrm{a}}$ \\
\hline C22:0 & $0.64 \pm 0.02^{\mathrm{c}}$ & $1.27 \pm 0.01^{\mathrm{a}}$ & $1.10 \pm 0.04^{\mathrm{b}}$ \\
\hline C24:0 & $1.20 \pm 0.04^{\mathrm{a}}$ & $0.28 \pm 0.02^{\mathrm{b}}$ & ND \\
\hline$\sum$ SFA & $34.92 \pm 0.03^{b}$ & $32.38 \pm 0.19^{c}$ & $46.60 \pm 0.07^{\mathrm{a}}$ \\
\hline $\mathrm{C} 14: 1$ & $0.27 \pm 0.01^{\mathrm{c}}$ & $0.40 \pm 0.01^{\mathrm{b}}$ & $1.12 \pm 0.02^{\mathrm{a}}$ \\
\hline C16:1 & $3.84 \pm 0.02^{c}$ & $5.25 \pm 0.03^{b}$ & $7.84 \pm 0.10^{\mathrm{a}}$ \\
\hline $\mathrm{C} 18: \ln 9 \mathrm{t}$ & $0.40 \pm 0.03^{\mathrm{b}}$ & $0.19 \pm 0.01^{c}$ & $0.67 \pm 0.02^{\mathrm{a}}$ \\
\hline $\mathrm{C} 18 \mathrm{in} 9 \mathrm{c}$ & $16.65 \pm 0.20^{\mathrm{b}}$ & $18.98 \pm 0.09^{\mathrm{a}}$ & $11.28 \pm 0.04^{\mathrm{c}}$ \\
\hline C20:1n9 & $1.24 \pm 0.08^{\mathrm{a}}$ & $1.13 \pm 0.06^{\mathrm{ab}}$ & $0.76 \pm 0.06^{\mathrm{c}}$ \\
\hline$\sum$ MUFA & $22.40 \pm 0.16^{a}$ & $25.96 \pm 0.09^{a}$ & $21.67 \pm 0.12^{a}$ \\
\hline
\end{tabular}




\begin{tabular}{|c|c|c|c|}
\hline Fatty acids & $\begin{array}{l}\text { Artemia } \\
\text { (T-1) }\end{array}$ & $\begin{array}{l}\text { Rotifer + Artemia } \\
\text { (T-2) }\end{array}$ & $\begin{array}{l}\text { Rotifer + Inert } \\
\text { (T-3) }\end{array}$ \\
\hline $\mathrm{C} 18: 2 \mathrm{n} 6 \mathrm{t}$ & $0.22 \pm 0.01^{\mathrm{b}}$ & ND & $0.60 \pm 0.08^{\mathrm{a}}$ \\
\hline $\mathrm{C} 18: 2 \mathrm{n} 6 \mathrm{c}$ & $5.92 \pm 0.02^{\mathrm{c}}$ & $7.39 \pm 0.03^{b}$ & $14.25 \pm 0.19^{\mathrm{a}}$ \\
\hline C20:2 & $1.13 \pm 0.02^{\mathrm{b}}$ & $1.35 \pm 0.01^{\mathrm{a}}$ & $0.49 \pm 0.02^{\mathrm{c}}$ \\
\hline C18:3n3 (ALA) & $4.42 \pm 0.04^{\mathrm{b}}$ & $5.64 \pm 0.01^{\mathrm{a}}$ & $2.69 \pm 0.06^{\mathrm{c}}$ \\
\hline $\mathrm{C} 20: 3 \mathrm{n} 3$ & $0.25 \pm 0.01^{\mathrm{bc}}$ & $0.26 \pm 0.00^{\mathrm{b}}$ & $0.92 \pm 0.02^{\mathrm{a}}$ \\
\hline C20:5n3 (EPA) & $23.20 \pm 0.09^{\mathrm{a}}$ & $17.32 \pm 0.19^{\mathrm{b}}$ & $1.28 \pm 0.11^{\mathrm{c}}$ \\
\hline C22:6n3 (DHA) & $0.90 \pm 0.01^{\mathrm{c}}$ & $3.82 \pm 0.11^{\mathrm{b}}$ & $10.30 \pm 0.43^{\mathrm{a}}$ \\
\hline C18:3n6 & ND & $0.20 \pm 0.00^{\mathrm{b}}$ & $0.75 \pm 0.02^{\mathrm{a}}$ \\
\hline C20:3n6 & $6.44 \pm 0.03^{\mathrm{a}}$ & $4.95 \pm 0.03^{b}$ & ND \\
\hline C20:4n6 (ARA) & $0.19 \pm 0.03^{\mathrm{c}}$ & $0.26 \pm 0.03^{\mathrm{b}}$ & $0.45 \pm 0.02^{\mathrm{a}}$ \\
\hline$\sum$ PUFA & $42.68 \pm 0.19^{a}$ & $41.65 \pm 0.26^{b}$ & $31.73 \pm 0.19^{c}$ \\
\hline$\sum \mathrm{UFA}$ & $65.08 \pm 0.03^{\mathrm{b}}$ & $67.62 \pm 0.19^{\mathrm{a}}$ & $53.40 \pm 0.07^{\mathrm{c}}$ \\
\hline$\sum(n-3)$ & $28.77 \pm 0.11^{\mathrm{a}}$ & $27.03 \pm 0.30^{\mathrm{b}}$ & $15.19 \pm 0.42^{\mathrm{c}}$ \\
\hline$\sum(n-6)$ & $6.63 \pm 0.06^{\mathrm{a}}$ & $5.41 \pm 0.04^{\mathrm{b}}$ & $1.20 \pm 0.04^{\mathrm{c}}$ \\
\hline UFA: SFA & $1.86 \pm 0.00: 1^{\mathrm{b}}$ & $2.09 \pm 0.02: 1^{\mathrm{a}}$ & $1.15 \pm 0.01: 1^{\mathrm{c}}$ \\
\hline$(n-6):(n-3)$ & $0.23 \pm 0.00: 1^{\mathrm{a}}$ & $0.20 \pm 0.00: 1^{\mathrm{b}}$ & $0.08 \pm 0.00: 1^{\mathrm{c}}$ \\
\hline DHA: EPA & $0.04 \pm 0.00: 1^{\mathrm{bc}}$ & $0.22 \pm 0.00: 1^{\mathrm{b}}$ & $8.09 \pm 0.97: 1^{\mathrm{a}}$ \\
\hline
\end{tabular}

Notes: $\mathrm{ND}=$ not detected; different superscript in same row indicate significant differences $(\mathrm{p}<0.05)$, shared superscripts indicate similarity, and $a>b>c>d$.

The lowest level $(31.73 \%)$ of PUFA was in T3, in which larvae was cultured with rotifer followed by commercial diet. Both n-3 and n-6 fatty acids were statistically different $(\mathrm{p}<0.05)$ among the treatments with the highest level in megalopa sample obtained from T1, followed by T2 and T3. Both EPA and DHA also differed statistically $(\mathrm{p}<0.05)$ among megalopa of all treatments. The EPA was highest $(23.20 \%)$ in $\mathrm{T} 1$, followed by T2 (17.32\%) and T3 (1.28\%), while the DHA was highest $(10.30 \%)$ in T3 followed by $\mathrm{T} 2(3.82 \%)$ and $\mathrm{T} 1(0.90 \%)$.

\section{Discussion}

Better survival rate and earliest metamorphosis to the subsequent larval stages are the utmost expectation in crustacean larvae rearing. Newly hatched mud crab larvae which lacks of yolk sac are hungry and need immediate feeding [35-37]. They are free swimmer and natural predator to the live prey, but the swimming activities of Z1 larvae are not so swift as to capture prey of the first movable objects, that indicates inefficient predator behavior and are passive feeders depending on options of encounter with food [38]. Thus, first feeding is found to be vital to minimize the initial mortality and to enhance the vitality for successful metamorphosis into subsequent larval stages. Availability of feeds, their size, digestibility and nutritional quality should be considered. In this larvae rearing experiment, the survival rate at the Z2 stage was similar in $\mathrm{T} 2$ and $\mathrm{T} 3$, where larvae were allowed to feed with enriched rotifer. On the other hand, larvae in the same stage in T1 that were fed with Artemia umbrella provided lower survival rate (Fig. 2 and Table 5). This indicated the suitability of rotifers as initial feeding of mud crab larvae rearing by virtue of their smaller size compatible to the mouth gap of the larvae [39-41]. In this 
experiment, rotifer enriched with algae (Nannochloropsis sp.) might have enhanced the digestibility of the newly hatched larvae, which ultimately benefitted the larvae by developing their digestive system $[42,43]$. On the other hand, feeding with umbrella stage Artemia (T1) was ultimately a mixture of umbrella and nauplii, while some remained in cyst forms, as because of asynchronized hatching of the Artemia. Mud crab larvae at the Z1 stage were unable to penetrate the shell of Artemia cyst [44]. Moreover, the Artemia nauplii were bigger in size than the mouth gap of the larvae. These physical features of the Artemia, might have lowered the survival rate of $\mathrm{Z} 2$ in $\mathrm{T} 1$ in this experiment.

In terms of nutritional content in this experiment, rotifers contained a high amount of EPA and DHA in compared to Artemia (Table 4). Zooplankton fed with phytoplankton (Nannochloropsis sp.) stored a vast amount of wax esters rich in HUFA's (highly unsaturated fatty acids), which are able to support the metabolic activity and cell membrane development. Though mud crab larvae consumed Artemia umbrella, they were not suitable to meet the nutritional demands for sustainable survival and successful metamorphosis to the later stages. A significant improvement in survival was noticed when only the Artemia was enriched [44]. Similar observations were made in the larvae rearing of the Chinese mitten crab Eriocheir sinensis [45]. Meanwhile, successful results in mud crab larvae rearing was reported as fed solely with umbrella type Artemia or combined rotifer and Artemia umbrella as initial feed [40], thus supporting the results of $\mathrm{T} 1$ in this experiment.

In this experiment, larvae fed with enriched rotifer up to Z2 and later on feeding on enriched Artemia nauplii, showed better survival rates, development and metamorphosis to megalopa at $15 \mathrm{DAH}$ (day at hatching) and successfully reached to the crablet stage (Figs. 2-3 and Tables 5-6). Similar outcomes were recorded for S. serrata larvae rearing in Australia and in Japan [46]. However, significant differences in the survival of mud crab larvae were not observed when only Artemia was enriched. But significantly faster development at $15 \mathrm{DAH}$ (day at hatching) was recorded by feeding with enriched rotifer for the first 6 days after hatching in Vietnam [47].

The larvae of T3 in this study, reared with enriched rotifer up to Z2 and followed by commercial diet, showed lower survival rate in the later stages of rearing (Fig. 2), lingered the intermoult period (Fig. 3 and Table 6) and were unable to moult in the crablet stage. All these might have happened due to physical properties of the diet. In visual observations, the commercial diet was found to float over water for some times, attached to the tank walls and after absorbing water the feed slowly sank to the bottom and formed a slimy layer. It was assumed that major portion of the nutrient, thus leaked into the water and deteriorated the culture tank by elevating $\mathrm{NH}_{4}$ (Fig. 1). Mass mortality of larvae in this treatment might be associated with lingering of the intermoult period (Table 6). Excess deposition of DHA in megalopa (Table 8) might another possible causative factor in sudden mortality of larvae in T3, as also observed previously [43], and in coupled with environmental stress due to elevated ammonia level (Fig. 1). In this experiment, larvae in T3 (fed with commercial diet) failed to reach the crablet stage. Meanwhile, formulated 
feed developed for marine shrimp larvae had some success in mud crab larvae rearing [48].

In this experiment, a portion of larvae (10 to $25 \%$ ) was found to contain additional growth or deformities in chelipod, improper exuvia shedding in comparison to the normal larvae of Z5 stage; and faced moulting difficulties. In addition, megalopa which took a longer time for metamorphosis also encountered moulting problem with the deformity in chelipods and eventually died during, immediately after or within 2 days after metamorphosis into the megalopa stage.

Such types of moulting failure and mortality during moulting from Z5 stage to megalopa and at the megalopa stage was earlier mentioned in $S$. serrata and $S$. paramamosain larvae rearing as well as in swimming crab larvae rearing $[49,50]$ and it was associated with improper nourishment of essential fatty acids [51]. Actually, when live feeds (rotifer or Artemia) were enriched, all the live feed did not receive equal amounts of enrichment. Meanwhile, nutrients in the live feed gradually decreased as the time passed after enrichment. In addition, larvae rearing in larger vessels (1000 L volume) did not allow uniform distribution of prey. Moreover, all the larvae did not eat at the same time and the same amount of feed. Thus the fast feeder larvae might receive a large amount of nutrients while the slow or late feeder might receive a low amount. Both excess and/or shortage in the essential n-3 fatty acids (HUFA's) like the EPA (20:5n-3) and DHA (22:6n-3) were reported as being responsible for such types of abnormal growth in Z5 as well as deformities at the megalopa stage $[11,13]$ and mass mortality occurred due to excessive levels of DHA [51].

Despite the gradual mortalities in some larval stages, larvae of T1 and T2 in this experiment successfully reached to the crablet stage, but not the larvae in T3. The reasons behind this might be the different ratios in EPA and DHA in the megalopa samples. Better survival of Scylla tranquebarica was obtained when DHA: EPA ration was lower (0.07) [20]. Similarly, superior survival and earliest metamorphosis of Scylla serrata larvae was reported with a DHA: EPA of 0.3 [13]. Whilst, in Vietnam, for Scylla paramamosain, first growth and metamorphosis were triggered by DHA: EPA ratio of 0.6 to 4 [47]. This indicated variations in fatty acid requirements for different species and locations. Therefore, with respect to the DHA/ EPA ratio (Table 4 and 8), the results of this experiment is in agreement with the findings of previous researcher [13, 20, 47, 51].

\section{Conclusion}

The results of this experiment revealed that, enriched rotifer as a first feeding followed by enriched Artemia nauplii for later stage feeding provided better performance in terms of growth, metamorphosis and survival. Commercial diet could be used at a minimum level as supplemental in combination with natural feeds. The level of enrichment with specific fatty acids (EPA and DHA) and their specific ratios need to be emphasized in future studies for the enhancement of the larvae rearing protocol. 


\section{Acknowledgment}

The research findings presented herein is part of $\mathrm{PhD}$ study of the corresponding author and were solely funded by the Bangladesh Agricultural Research Council (BARC) through the NATP Phase-1 project. The Universiti Sains Malaysia (USM) is also deeply acknowledged for providing research space at Centre for Marine and Coastal Studies (CEMACS) and worthy laboratory facilities for sample analysis.

\section{References}

1. M. A. Suprayudi, T. Takeuchi, K. Hamasaki, and J. Hirokawa, Fish. Sci. 68(6), 1295 (2002). http://dx.doi.org/10.1046/j.1444-2906.2002.00567.x

2. C. P. Keenan. The Fourth Species of Scylla, In Mud Crab Aquaculture and Biology, - Proc. of an Int. Scientific Forum, ed. C. P. Keenan et al. (Darwin, Australia, 21-24 April, 1997). ACIAR Proceedings No. 78. Watson Ferguson and Company, (Brisbane, Australia, 1999) pp. 48-58.

3. J. R. Sargent, M. V. Bell, R. J. Henderson, and D. R. Tochler, Animal Nutrition and Transport Processes I. Nutrition in Wild and Domestic Animals, ed. J. Mellinger, Comp. Physiol. 5, (Karger, Basel, 1990) pp. 11-23.

4. C. Shelley, Capture-based Aquaculture of Mud Crabs (Scylla spp.) In Capture-based aquaculture, Global Overview, A. Lovatelli and P. F. Holthus, FAO Fisheries Technical Paper, 508 (FAO, Rome, 2008) pp. 255-269.

5. E. T. Quinitio and M. M. N. Lwin. Soft-shell Mud Crab Farming, A Practical Manual, (Southeast Asian Fisheries Development Center Aquaculture Department, Tigbauan, lloio, Philippines, 2009).

6. E. T. Quinitio, F. D. Parado-Estepa, O. M. Millamena, E. Rodriguez, and E. Borlongan, Asian Fish. Sci. 14, 161 (2001).

7. T. T. Nghia, PhD thesis, Gent University, Belgium (2005).

8. M. L. Islam and K. Yahya, Int. J. Fish. Aquat. Stud. 4(5), 270 (2016).

9. M. N. Azra and M. Ikhwanuddin, Saudi J. Biol. Sci. 23, 257 (2016). http://dx.doi.org/10.1016/j.sjbs.2015.03.011

10. K. Hamasaki, M. A. Suprayudi, and T. Takeuchi, Suisanzoshoku 50(3), 333 (2002).

11. K. Hamasaki, M. A. Suprayudi, and T. Takeuchi, Fisheries Sci. 68, 1226 (2002). http://dx.doi.org/10.1046/j.1444-2906.2002.00559.x

12. D. L. Mann, T. Asakawa, M. Pizzuto, C. P. Keenan, and I. J. Brock, Asian Fish. Sci. 14(2), 175 (2001).

13. M. A. Suprayudi, T. Takeuchi, K. Hamasaki, and J. Hirokawa, Suisanzoshoku, 50(2), 205 (2002).

14. C. Zeng and S. S. Li. Effects of Density and Different Combinations of Diets on Survival, Development, Dry Weight and Chemical Composition of Larvae of the Mud Crab Scylla paramamosain, In Mud crab aquaculture and biology - Proc. of an Int. Scientific Forum, ed. C. P. Keenan et al. (The Bribie Island Aquaculture Research Center, Darwin Northern Territory. Australia, 1999) pp. 159-166.

15. M. A. Crawford, M. Bloom, C. L. Broadhurst, W. F. Schmidt, S. C. Cunnane, C. Galli, K. Gehbremeskel, F. Linseisen, J. Lloyd-Smith, and J. Parkington, Lipids. 34(1), 39 (1999). http://dx.doi.org/10.1007/BF02562227

16. F. Sahena, I. S. M. Zaidul, S. Jinap, N. Saari, H. A. Jahurul, K. A. Abbas, and N. A. Norulaini, Rev. Food Sci. Food Safety 8(2), 59 (2009). http://dx.doi.org/10.1111/j.1541-4337.2009.00069.x

17. S. B. Barbara, F. T. Michael, L. B. Jeannie, and C. S. David, Neurosci. Lett. 415(2), 154 (2007). 
http://dx.doi.org/10.1016/j.neulet.2007.01.010

18. G. M. L. Felix, D. M. Gatlin, A. L. Lawrence, and M. Perez-Velazquez, J. World Aquacult. Soc. 33(3), 330 (2002). http://dx.doi.org/10.1111/j.1749-7345.2002.tb00509.x

19. A. Kanazawa, S. Teshima, and K. Ono, Compara. Biochem. Physiol. 63(B), 295 (1979a).

20. T. Kobayashi, T. Takeuchi, D. Arai, and S. Sekiya, Bull. Japan. Soc. Sci. Fish. 66 (6), 1006 (2000). http://dx.doi.org/10.2331/suisan.66.1006

21. T. Takeuchi, N. Yoshihiko, K. Hamasaki, S. Sekiya, and T. Watanabe, Bull. Japan Soc. Sci. Fish. 65(5), 797 (1999). http://dx.doi.org/10.2331/suisan.65.797

22. N. C. Thach. Seed Production and Grow-out of Mud Crab (Scylla paramamsain) in Vietnam, Aquaculture Extension Manual (Southeast Asian Fisheries Development Center, Aquaculture Department Tigbauan, lloio, Philippines, 2009). (ADQ Website: http://www.seafdec.org.ph)

23. E. T. Quinitio and F. D. Parado-Estepa. Biology and Hatchery of Mud Crab Scylla spp. Aquaculture Extension Manual no. 34. $2^{\text {nd }}$ Edition (Southeast Asian Fisheries Development Center Aquaculture Department Tigbauan, lloio, Philippines, 2008).

24. R. R. L. Guillard. Division Rates in Handbook of Phycological Methods, In Culture Methods and Growth Measurements ed. R. Etein (Chambridge University Press, Chambridge, 1973) pp. 289-311.

25. Hatchery Culture of Bivalves, A Practical Manual. FAO Fisheries Technical Paper No. 471, ed. M. H. Helm et al. (Food and Agricultural Organization of the United Nations, Rome, 2004) p. 177.

26. Manual on the Production and Use of Live Food for Aquaculture. FAO Fisheries Technical Paper No. 361, ed. P. Lavens et al. (Food and Agricultural Organization of the United Nations, Rome, 1996) p. 295.

27. G. Lumasag and E. T. Quinitio, Ingestion Rate of Mud Crab (Scylla serrata) Larvae After Delayed Feeding, In Extended Abstracts of International Forum on the Culture of Portunid Crabs (Boracay, Philippines, 1-4 December, 1998) p. 29.

28. FAO. Food and Agriculture Organization of the United Nations. Manual on the Production and Use of Live Food for Aquaculture, FAO Fisheries Technical Paper 361 (Rome, Italy, 1996).

29. C. P. Keenan, P. J. F. Davie, and D. L. Mann, Raffles Bul. Zool. 46(1), 217 (1998).

30. APHA (American Public Health Association), Standard Methods for the Examination of Water and Wastewater, $18^{\text {th }}$ Edition (APHA, Washington, D.C. 1992) pp. 1266.

31. M. Ikhwanuddin, A. D. Talpur, and M. N. Azra, World Applied Sci. J. 18 (3), 379 (2012).

32. O. M. Millamena and J. P. Bangcaya, Asian Fish. Sci. 14, 153 (2001).

33. J. Floch, M. Lees, and M. Sloane-Stanley, J. Biol. Chem. 226, 497 (1957).

34. E. Indarti, M. I. A. Majid, R. Hashim, and A. S. Chong, J. Food Composit. Analy. 18, 161 (2005). http://dx.doi.org/10.1016/j.jfca.2003.12.007

35. I. S. Djunaidah, M. Wille, E. K. Kontara, and P. Sorgeloos, Aquacult. Int. 11(1-2), 3 (2003). http://dx.doi.org/10.1023/A:1024188507215

36. S. Li, C. Zeng, H. Tang, F. Li, G. Wang, Y. Cheng, and Q. Lin, J. Oceanograp. Taiwan Strait. 17, 9 (1998).

37. S. Li, C. Zeng, H. Tang, F. Li, G. Wang, Y. Cheng, and Q. Lin, Investigations into the Reproductive and Larval Culture Biology of the Mud Crab, Scylla paramamosain: a Research Overview - Proc. of Mud Crab Aquaculture and Biology Workshop, ed. A. W. Blackshaw et al. (The Bribie Island Aquaculture Research Center, Darwin Northern Territory, Australia, 1999) pp. 121-124.

38. M. P. Heasman, and D. R. Fielder, Aquacult. 34, 301 (1983). http://dx.doi.org/10.1016/0044-8486(83)90210-7

39. C. F. Chang and C. H. Wu., Bul. Taiwan Fish. Res. Ins. No. 39 (1985).

40. C. Shelly and A. Lovatelli, Mud Crab Aquaculture, a Practical Manual. FAO, Fisheries and Aquaculture Technical Paper, 567 (FAO, Rome, 2011).

41. N. Thirunavukkarasu, C. S. A. Nesakumari, and A. A. Shanmugam, Int. J. Fish. Aquat. Stud. 2(2), 19 (2014). 
42. Manual on the Production and Use of Live Food for Aquaculture, FAO Technical paper no. 361, ed. P. D. Rotifers et al. (1996) pp. 61-100.

43. T. Watanabe, T. Arakawa, C. Kitajima, and S. Fujita, Bul. Japan. Soc. Sci. Fish. 44(9), 985 (1978). http://dx.doi.org/10.2331/suisan.44.985

44. Manual on the Production and Use of Live Food for Aquaculture. FAO technical paper No. 361, ed. G. V. Stappen et al. (Food and Agricultural Organization, Rome, 1996) pp. 101-170.

45. L. Y. Sui, PhD thesis, Gent University, Belgium (2008).

46. J. A. Davis, PhD thesis, University of Ghent, Belgium (2004).

47. S. Vandendriessche, MSc Thesis, Ghent University, Ghent, Belgium (2003).

48. E. T. Quinitio, F. D. Parado-Estepa and V. Alava, Development of Hatchery Techniques for the Mud Crab Scylla serrata I: Comparison of Feeding Schemes - Proc. of Mud Crab Aquaculture and Biology Workshop, ed. A. Blackshaw et al. (Darwin Northern Territory, Australia, 1999) pp. 125-130.

49. D. Arai, K. Hamasaki, K. Maruyama, Y. Obata, S. Tsumura, and M. Takano, Nippon Suisan Gakkaishi 70, 567 (2004). http://dx.doi.org/10.2331/suisan.70.567

50. D. Arai, T. Takeuchi, D. Sugita, K. Hamasaki, and K. Maruyama, Aquacult. Sci. 55, 133 (2007).

51. M. A. Suprayudi, T. Takeuchi, and K. Hamasaki, Science 70, 650 (2004).

http://dx.doi.org/10.1111/j.1444-2906.2004.00853.x 